\title{
Focus on apoptosis to decipher how alcohol and many other drugs disrupt brain development
}

\author{
John W. Olney* \\ Department of Psychiatry, Washington University School of Medicine, St. Louis, MO, USA \\ ${ }^{*}$ Correspondence: olneyj@wustl.edu \\ Edited by: \\ Andrea De Giorgio, Catholic University, Italy \\ Reviewed by: \\ Alberto Granato, Catholic University, Italy
}

Keywords: apoptosis, developing brain, neurons, oligodendrocytes, alcohol, sedatives, anesthetics, anti-epileptics

Maternal ingestion of alcohol during pregnancy can cause a disability syndrome termed fetal alcohol spectrum disorder (FASD), which may include craniofacial malformations, gross structural brain pathology, and a variety of long-term neuropsychiatric disturbances, or it may consist of subtle brain changes and neuropsychiatric disturbances in the relative absence of gross dysmorphogenic features. Based on a large body of recent evidence, we have proposed (1) that most, if not all, of the deleterious effects of alcohol on the developing brain can be explained by a single mechanism. Alcohol has apoptogenic properties that cause large numbers of CNS progenitor cells, or fully differentiated brain cells (depending on developmental age at time of alcohol exposure) to commit suicide and be deleted from the pool of cells that would ordinarily survive and contribute to the normal functions of the brain. If excessive cell suicide is triggered by alcohol in a very early stage of development, the result, as Sulik and colleagues have shown (2), will be gross dysmorphogenic anomalies (e.g., craniofacial and midline brain anomalies), because the cells deleted are progenitor cells that are responsible for generating cell populations that comprise the building blocks of these craniofacial and brain structures. But if, as we have demonstrated (3-5), alcohol triggers suicide of CNS cells in later stages of development after these cells are already differentiating into neurons and glia, the result will be a reduced number of brain cells, derangement of brain circuitry, and various neuropsychiatric disturbances, depending on which populations of cells have been deleted and what combination of synaptic connections have been disrupted or destroyed.
Alcohol's apoptogenic action is linked to its NMDA glutamate antagonist and $G_{A B A}$ agonist properties. Many other drugs that have one or both of these properties also trigger developmental apoptosis, including other drugs of abuse (phencyclidine, ketamine, benzodiazepines, and barbiturates), and many drugs used in obstetric and pediatric medicine [all sedative/anesthetic drugs (SADs), and most anti-epileptic drugs (AEDs)] (3, 6-8). It was demonstrated quantitatively in early studies that neurons are permanently deleted from the developing brain by exposure to these drugs, and that brain volume is permanently reduced and synaptic ultrastructure disrupted. No region of the central nervous system is totally spared, in that the degenerative response has been demonstrated in neurons distributed widely throughout the forebrain, midbrain, cerebellum, brainstem, spinal cord, and retina (3, 4, 9-11). Although alcohol's apoptogenic action was originally thought to impinge only on neurons, it is now well established that oligodendrocytes (oligos), distributed diffusely throughout the white matter, also succumb to apoptosis following developmental exposure to alcohol or to SADs or AEDs (12-16). The injury induced by apoptogenic drugs is dose and developmental age-dependent, with several different patterns of neuronal degeneration observed, depending on developmental age at time of drug exposure. The cell death process involves Bax-mediated extramitochondrial leakage of cytochrome $c$ (17), which is followed by a sequence of changes culminating in the activation of caspase-3 $(5,18)$. An important property that apoptogenic drugs have in common is that they rapidly suppress phosphorylation of extracellular signal-regulated kinases (ERK) (signaling system that regulates cell survival) in the in vivo developing brain. This has potentially important implications for preventing this type of brain injury, in that lithium counteracts the suppressant action of apoptogenic drugs on pERK (19), and also protects against apoptogenic injury induced by these drugs in the infant mouse (19-21) or infant monkey brain (22).

The developing rhesus macaque brain is quite sensitive to the toxic action of apoptogenic drugs, and in both rodents and monkeys two specific cell types are affected neurons and oligos - and the mode of cell death for both cell types is apoptosis. Many of the structural brain changes reported in children with FASD are also seen in the brains of rodents and monkeys following exposure to alcohol and related apoptogenic drugs [illustrated extensively in Ref. (1)]. A prime example of a prominent structural brain change caused by alcohol and all other apoptogenic drugs following exposure of the primate brain in the early third trimester is loss of basal ganglia (BG) neuronal mass. This has long been recognized as a prominent finding in children who were exposed in utero to alcohol $(23,24)$, and also has been reported in children who were exposed to AEDs in the third trimester of gestation (25), and in premature infants who have learning disability following exposure to surgical anesthesia (26) or following prolonged sedation in the neonatal intensive care unit (27).

The window of vulnerability in primates appears to be very similar for all of these drugs. Valproate, an AED with very strong apoptogenic properties (7), mimics alcohol in causing craniofacial and midline brain anomalies following human exposure in 
the first trimester (28), and in causing a large IQ deficit following human exposure in the third trimester $(29,30)$. SADs have not been studied adequately for early dysmorphic effects, but we have shown that alcohol and numerous SADs (isoflurane, propofol, ketamine, benzodiazepines, and barbiturates) trigger a robust apoptosis response in the fetal monkey brain on gestational days 100-120 (comparable to human late second trimester), and vulnerability continues throughout the third trimester and up to a yet to be established age after birth (12-16, 31, 32). Mounting evidence from animal studies prompted a series of recent human studies, which have documented that brief anesthesia exposure of premature infants (26), or full term human infants (33-40) is associated with increased risk for neurocognitive deficits. Thus, it is clear that apoptogenicity is a property that alcohol and certain other drugs have in common, and emerging evidence suggests that in both early and late gestation these drugs have the potential to cause FASD-like structural brain changes and FASD-like neurodevelopmental disability syndromes. Available evidence suggests that FASD syndromes induced by anesthetic drugs are usually less severe than the syndrome that alcohol often causes, the obvious reason being that pregnant mothers who have a strong alcohol habit expose their fetuses multiple times during gestation to prolonged "binge" blood levels of alcohol, whereas the vast majority of human infants or fetuses who are exposed to anesthetic drugs are exposed only once for a relatively brief duration. Consistent with this thesis, the numerous human studies cited above are in good agreement that risk for poor neurocognitive outcome is greater following multiple anesthesia exposures than following a single exposure.

Although many mechanisms have been proposed to explain the FASD syndrome, the only mechanism identified, thus far, that can actually explain most if not all of the brain and behavioral pathology comprising that syndrome can be summed up in a single word - apoptosis. Within only a few hours after alcohol enters the developing brain, millions of brain cells that were on a healthy survival track, suddenly become derailed and commit suicide. The cells that die belong to both the neuronal and oligo lineages. Oligos are vitally important for normal neuronal function. Although widespread loss of neurons, or their progenitors, from the developing brain would be a sufficient mechanism to explain the signs and symptoms of FASD, simultaneous deletion of oligos, or their progenitors, makes the case even stronger for apoptosis as a single primary mechanism that can explain all features of the FASD syndrome. Once the apoptotic deletion of neurons and oligos (or their precursors) has occurred as the primary injurious event, there are numerous secondary mechanisms that come into play as the brain attempts to compensate for the disruptive influence of this primary injury. For example, loss of neurons causes an impoverishment of dendritic fields for receiving synaptic inputs from incoming axons, and loss of neurons also means there will be fewer axons to establish those synaptic contacts $(41,42)$. Developing brain networks must reconstitute and reorganize themselves to cope with this primary insult. Researchers can spend lifetimes studying the myriad steps in this reorganization process, but identifying these many features of the deranged and reorganized circuitry, will not yield insights necessary for preventing alcohol (or SADs and AEDs) from causing the initial injury and consequent derangements. The scenario I have just described pertains to a single episode of alcohol exposure. Consider how complicated the reorganization task will be for the brain of a fetus whose mother heavily abuses alcohol multiple times, both early and late, during pregnancy. Again, much time can be spent in studying this multi-layered complex reorganization process, but if the end goal is to learn how to prevent this type of developmental injury, the time will be better spent focusing on apoptosis as the primary cause, and deciphering the molecular mechanisms by which alcohol (or SADs and AEDs) unleash the apoptosis cascade. A better understanding of these mechanisms can lead to effective methods for preventing apoptogenic drugs from injuring the developing brain.

\section{ACKNOWLEDGMENTS}

Supported in part by grants from the United States National Institute of Child Health and Human Development (HD
052664, HD 37100, and HD 062171) and the National Institute of Drug Abuse (DA 05072).

\section{REFERENCES}

1. Creeley CE, Olney JW. Drug-induced apoptosis: mechanism by which alcohol and many other drugs can disrupt brain development. Brain Sci (2013) 3:1153-81. doi:10.3390/brainsci3031153

2. Dunty WC Jr, Chen SY, Zucker RM, Dehart DB, Sulik KK. Selective vulnerability of embryonic cell populations to ethanol-induced apoptosis: implications for alcohol-related birth defects and neurodevelopmental disorder. Alcohol Clin Exp Res (2001) 25:1523-35. doi:10.1111/j.1530-0277.2001. tb02156.x

3. Ikonomidou C, Bittigau P, Ishimaru MJ, Wozniak DF, Dikranian K, Olney JW, et al. Ethanolinduced apoptotic neurodegeneration and fetal alcohol syndrome. Science (2000) 287:1056-60. doi:10.1126/science.287.5455.1056

4. Olney JW, Tenkova T, Dikranian K, Muglia LJ, D'Sa C, Roth KA. Ethanol-induced caspase-3 activation in the in vivo developing mouse brain. $\mathrm{Neu}$ robiol Dis (2002) 9:205-19. doi:10.1006/nbdi.2001. 0475

5. Olney JW, Tenkova T, Dikranian K, Labruyere J, Qin QY, Ikonomidou C. Ethanol-induced apoptotic neurodegeneration in the developing C57BL/6 mouse brain. Brain Res Dev Brain Res (2002) 133:115-26. doi:10.1016/S0165-3806(02) 00279-1

6. Ikonomidou C, Bosch F, Miksa M, Bittigau P, Dikranian K, Olney JW, et al. Blockade of NMDA receptors and apoptotic neurodegeneration in the developing brain. Science (1999) 283:70-4. doi:10 . 1126/science. 283.5398 .70

7. Bittigau P, Sifringer M, Genz K, Dikranian K, Olney JW, Ikonomidou C, et al. Antiepileptic drugs and apoptotic neurodegeneration in the developing brain. Proc Natl Acad Sci US A (2002) 99:15089-94. doi:10.1073/pnas.222550499

8. Jevtovic-Todorovic V, Hartman RE, Dikranian K, Zorumski CF, Olney JW, Wozniak DF, et al. Early exposure to common anesthetics causes widespread neurodegeneration in the developing rat brain and persistent learning deficits. $J$ Neurosci (2003) 23:876-82.

9. Dikranian K, Qin YQ, Labruyere J, Nemmers $\mathrm{B}$, Olney JW. Ethanol-induced neuroapoptosis in the developing rodent cerebellum and related brain stem structures. Brain Res Dev Brain Res (2005) 155:1-13. doi:10.1016/j.devbrainres.2004. 11.005

10. Tenkova T, Young C, Dikranian K, Labruyere J, Olney JW. Ethanol-induced apoptosis in the visual system during synaptogenesis. Invest Ophthalmol Vis Sci (2003) 44:2809-17. doi:10.1167/iovs.020982

11. Sanders RD, Xu J, Shu Y, Fidalgo A, Ma D, Maze M. General anesthetics induce apoptotic neurodegeneration in the neonatal rat spinal cord. Anesth Analg (2008) 106:1708-11. doi:10.1213/ ane.0b013e3181733fdb

12. Creeley CE, Dikranian KT, Dissen GA, Olney JW, Brambrink AM. Propofol-induced apoptosis of neurons and oligodendrocytes in the fetal and 
neonatal rhesus macaque brain. Br J Anesth (2013) 110:129-38. doi:10.1093/bja/aet173

13. Creeley CE, Dikranian KT, Johnson SA, Farber $\mathrm{NB}$, Olney JW. Alcohol-induced apoptosis of oligodendrocytes in the fetal macaque brain. Acta Neuropathol Commun (2013) 1:1-11. doi:10.1186/ 2051-5960-1-23

14. Creeley CE, Dikranian KT, Back SA, Olney JW, Brambrink AM. Isoflurane-induced apoptosis of neurons and oligodendrocytes in the fetal rhesus macaque brain. Anesthesiology (2014) 120:626-38. doi:10.1097/ALN.0000000000000037

15. Brambrink AM, Evers AS, Avidan MS, Farber NB, Dissen GA, Olney JW, et al. Ketamine-induced neuroapoptosis in the fetal and neonatal rhesus macaque brain. Anesthesiology (2012) 116:372-84. doi:10.1097/ALN.0b013e318242b2cd

16. Brambrink AM, Back SA, Riddle A, Dissen GA, Dikranian K, Olney JW, et al. Isoflurane-induced apoptosis of oligodendrocytes in the neonatal primate brain. Ann Neurol (2012) 72:525-35. doi:10. 1002/ana.23652

17. Young C, Klocke J, Tenkova T, Holtzman DM, Roth KA, Olney JW, et al. Ethanol-induced neuronal apoptosis in the in vivo developing mouse brain is BAX dependent. Cell Death Differ (2003) 10:1148-55. doi:10.1038/sj.cdd.4401277

18. Young C, Roth KA, Klocke BJ, West T, Holtzman DM, Labruyere J, et al. Role of caspase-3 in ethanol-induced developmental neurodegeneration. Neurobiol Dis (2005) 20:608-14. doi:10. 1016/j.nbd.2005.04.014

19. Young C, Straiko MM, Johnson SA, Creeley C, Olney JW. Ethanol causes and lithium prevents neuroapoptosis and suppression of pERK in the infant mouse brain. Neurobiol Dis (2008) 31:355-60. doi:10.1016/j.nbd.2008.05.009

20. Zhong J, Yang X, Yao W, Lee W. Lithium protects ethanol-induced neuronal apoptosis. Biochem Biophys Res Commun (2006) 350:905-10. doi:10.1016/ j.bbrc.2006.09.138

21. Straiko MMW, Young C, Cattano D, Creeley CE, Wang H, Smith DJ, et al. Lithium protects against anesthesia-induced developmental neuroapoptosis. Anesthesiology (2009) 110:862-8. doi:10.1097/ ALN.0b013e31819b5eab

22. Brambrink AM, Johnson SA, Dissen G, Martin LD, Kristich LE, Noguchi K, et al. Lithium protects against anesthesia neurotoxicity in the infant primate brain. American Society of Anesthesiologists, Annual Meeting Program. (2014) (in press).

23. Mattson SN, Riley EP, Sowell ER, Jernigan TL, Sobel DF, Jones KL. A decrease in the size of the basal ganglia in children with fetal alcohol syndrome. Alcohol Clin Exp Res (1996) 20:1088-93. doi:10.1111/j.1530-0277.1996.tb01951.x

24. Riley EP, McGee CL. Fetal alcohol spectrum disorders: an overview with emphasis on changes in brain and behavior. Exp Biol Med (2005) 230:357-65.
25. Ikonomidou C, Scheer I, Wilhelm T, Lehmkuhl U, Koch S, Kassubek J, et al. Brain morphology alterations in the basal ganglia and the hypothalamus following prenatal exposure to antiepileptic drugs. Eur J Paediatr Neurol (2007) 11:297-301. doi:10.1016/j.ejpn.2007.02.006

26. Filan PM, Hunt RW, Anderson PJ, Doyle LW, Inder TE. Neurologic outcomes in very preterm infants undergoing surgery. J Pediatr (2012) 160:409-14. doi:10.1016/j.jpeds.2011.09.009

27. Omizzolo C, Scratch SE, Stargatt R, Kidokoro $\mathrm{H}$, Thompson DK, Lee KJ, et al. Neonatal brain abnormalities and memory and learning outcomes at 7 years in children born very preterm. Memory (2014) 22:605-15. doi:10.1080/09658211. 2013.809765

28. Ardinger $\mathrm{HH}$, Atkin JF, Blackston RD, Elsas LJ, Clarren SK, Livingstone S, et al. Verification of the fetal valproate syndrome phenotype. Am J Med Genet (1988) 29:171-85. doi:10.1002/ajmg. 1320290123

29. Meador KJ; NEAD Study Group. Cognitive function at 3 years of age after fetal exposure to antiepileptic drugs. N Engl J Med (2009) 360:1597-605. doi:10.1056/NEJMoa0803531

30. Meador KJ; NEAD Study Group. Effects of fetal antiepileptic drug exposure: outcomes at age 4.5 years. Neurology (2012) 78:1207-14. doi:10.1212/ WNL.0b013e318250d824

31. Farber NB, Creeley CE, Olney JW. Alcohol-induced neuroapoptosis in the fetal macaque brain. Neurobiol Dis (2010) 40:200-6. doi:10.1016/j.nbd.2010. 05.025

32. Brambrink AM, Evers AS, Avidan MS, Farber NB, Dissen GA, Olney JW, et al. Isoflurane-induced neuroapoptosis in the neonatal rhesus macaque brain. Anesthesiology (2010) 112:834-41. doi:10. 1097/ALN.0b013e3181d049cd

33. DiMaggio C, Sun LS, Kakavouli A, Byrne MW, Li GA. Retrospective cohort study of the association of anesthesia and hernia repair surgery with behavioral and developmental disorders in young children. J Neurosurg Anesthesiol (2009) 21:286-91. doi:10.1097/ANA.0b013e3181a71f11

34. DiMaggio CJ, Sun LS, Li G. Early childhood exposure to anesthesia and risk of developmental and behavioral disorders in a sibling birth cohort. Anesth Analg (2011) 113:1143-51. doi:10.1213/ ANE.0b013e3182147f42

35. Wilder RT, Flick RP, Sprung J, Katusic SK, Barbaresi WJ, Mickelson C, et al. Early exposure to anesthesia and learning disabilities in a population-based birth cohort. Anesthesiology (2009) 110(4):796-804. doi:10.1097/01.anes. $0000344728.34332 .5 \mathrm{~d}$

36. Flick RP, Katusic SK, Colligan RC, Wilder RT, Voigt RG, Olson MD, et al. Cognitive and behavioral outcomes after early exposure to anesthesia and surgery. Pediatrics (2011) 128(5):e1053-61. doi:10.1542/peds.2011-0351
37. Sprung J, Flick RP, Katusic SK, Colligan RC, Barbaresi WJ, Bojanic K, et al. Attentiondeficit/hyperactivity disorder after early exposure to procedures requiring general anesthesia. Mayo Clin Proc (2012) 87(2):120-9. doi:10.1016/j. mayocp.2011.11.008

38. Block RI, Thomas JJ, Bayman EO, Choi JW, Kimble KK, Todd MM. Are anesthesia and surgery during infancy associated with altered academic performance during childhood? Anesthesiology (2012) 117:494-503. doi:10.1097/ALN. 0b013e3182644684

39. Ing C, DiMaggio C, Whitehouse A, Hegarty MK, Brady J, von Ungern-Sternberg BS, et al. Longterm differences in language and cognitive function after childhood exposure to anesthesia. Pediatrics (2012) 130(3):e476-85. doi:10.1542/peds. 2011-3822

40. Andropoulos DB, Ahmad HB, Haq T, Brady $\mathrm{K}$, Stayer SA, Meador MR, et al. The association beween brain injury, perioperative anesthetic exposure, and 12 month neurodevelopmental outcomes after neonatal cardiac surgery: a retrospective cohort study. Pediatr Anesth (2014) 24:266-74. doi:10.1111/pan.12350

41. Lunardi N, Ori C, Erisir A, Jevtovic-Todorovic V. General anesthesia causes long-lasting disturbances in the ultrastructural properties of developing synapses in young rats. Neurotox Res (2010) 17:179-88. doi:10.1007/s12640-0099088- Z

42. Forcelli PA, Janssen MJ, Vicini S, Gale K. Neonatal exposure to antiepileptic drugs disrupts striatal synaptic development. Ann Neurol (2012) 72:363-72. doi:10.1002/ana.23600

Conflict of Interest Statement: The author declares that the research was conducted in the absence of any commercial or financial relationships that could be construed as a potential conflict of interest.

Received: 09 July 2014; accepted: 18 July 2014; published online: 04 August 2014.

Citation: Olney JW (2014) Focus on apoptosis to decipher how alcohol and many other drugs disrupt brain development. Front. Pediatr. 2:81. doi: 10.3389/fped.2014.00081

This article was submitted to Child and Neurodevelopmental Psychiatry, a section of the journal Frontiers in Pediatrics.

Copyright (c) 2014 Olney. This is an open-access article distributed under the terms of the Creative Commons Attribution License (CC BY). The use, distribution or reproduction in other forums is permitted, provided the original author(s) or licensor are credited and that the original publication in this journal is cited, in accordance with accepted academic practice. No use, distribution or reproduction is permitted which does not comply with these terms. 